\title{
CULTURAL HERITAGE OF PAŁUKI IN RELATION TO DEVELOPMENT OF AGRITOURISM IN THE REGION
}

\author{
JOLANTA CICHOWSKA
}

University of Science and Technology Bydgoszcz

e-mail: jolanta.cichowska@utp.edu.pl

\begin{abstract}
\begin{tabular}{l|l} 
JEL CODES & Z32
\end{tabular}
KEYWORDS tourism rural, agritourism, cultural heritage, Pałuki

ABSTRACT The goal of this study is to find out whether the cultural aspect of the Pałuki region finds reflection in how agritourist farms of this area are viewed by the farm owners and tourists. The survey was based on a TDI (telephone deepened interview) anonymous questionnaire. It was carried out in May 2017 and it was of widespread character (all 24 non-agricultural activities reported of the Pałuki region were taken into consideration). The method used in the survey allowed to find out whether or not the cultural heritage of the analyzed region is attractive for agritourist farm owners. The method used in the research enabled to find out the respondents' attitude to promotion of the region. They were also asked whether culture oriented tourism can provide measurable economic profits.
\end{abstract}

\section{Introduction}

Cultural heritage is a complex issue and it can hardly be defined as it includes many aspects. Its primary function is to provide knowledge of the lifestyle of former generations. Cultural heritage also takes into account the landscapes transformed by man so it can be said that it is the history of places and people who have lived in them. Such a legacy left by ancestors is very important as it defines peoples' identity, which in turn is a factor integrating local communities and motivating 
them to cooperate (Hełpa-Liszkowska, 2013, p. 8). Agritourist farms play a very important role in preserving traditions and customs. Ziernicka-Wojtaszek and Zawora (2010, p. 120) emphasize that keeping traditions and customs alive is a very important function of rural communities as they create distinctive traditions which can be used as tourist attractions of ethnographic character. The goal of this study is to answer the question whether the cultural heritage of Pałuki is included in agritourist farm offers. The survey covered all agritourist farms of this region. It was assumed that most of the farmers would be willing to include the cultural potential of the region in their tourist offers, providing the visitors with the possibility of getting familiar with the historical diversity of Pałuki.

\section{Research method}

In order to verify the accepted hypothesis and achieve the research goal, an interview questionnaire was used. According to the method of diagnostic survey, the respondents were asked 19 questions on the phone, 7 of which were of closed formula. The questions to be answered were as follows: what is the condition of the agritourist infrastructure of Pałuki? Are agritourist farm owners of the opinion that the Pałuki region is attractive for tourists and which objects and sites they find worth visiting? Are the offers of agritourist farms based on elements of cultural heritage and farm specific activities? What is economic profitability of nonagricultural activities?

The survey covered the whole considered group, so it was fairly explicit. It was performed in May 2017. Address details of agritourist farms situated on the territory of Pałuki, were obtained from official webpages of local offices and tourist portals. Out of 25 farm owners providing agritourist services, only one did not participate in the survey. This was caused by closure of the business in 2016.

The assessment of agritourist activities will not be based on typical absolute measures accepted in economy for determination of management (income: global, agricultural, personal, pure) and relative measures, commonly referred to as indexes (Bednarski 1998, pp. 70-79). These will be estimated (unsupported by evidence) using data based only on the opinion of agritourist farm owners.

\section{Characteristics of the research}

Pałuki - historic-ethnographic region which lies on the border of the following voiviodships: Kujawsko-Pomorskie (districts: Nakło, Szubin and Żnin) and Wielkopolskie (districts: Chodzież, Oborniki and Wągrowiec), is an area with outstanding natural-cultural advantages. In the northeast, its border is the Noteć river (separating it from Krajna and Kujawy), in the north and south Chomiąskie Lake, Gąsawskie Lake and the Wełna river (starting with Rogowskie Lake), and in the west the Rudka river, Tyśmienica, (Dymnica), Margonina rivers (Figure 1). The region covers an area of 2,100 $\mathrm{km}^{2}$ and does not have one capital, though there are a few towns that compete for the title, including: Kcynia (the oldest town in Pałuki; municipal rights granted in 1262), Szubin (the main native town of Pałuki) and Żnin (one of the biggest towns of the region). Pałuki boast 
a big amount of tourist attractions. One of the most interesting locations worth sightseeing is a reconstructed Iron Age Slavic settlement in Biskupin. Żnin in turn, is famous for its Gothic Tower, which accommodates a Museum of Pałuki Land. Another place worth sightseeing is Wenecja due to its ruined castle located near the Museum of Narrow Gauge Railway which is picturesquely situated between three lakes (Weneckie, Biskupińskie and Skrzynka) on the Piastowski Trail (linking three capital towns - Poznań, Gniezno and Kruszwica), whose significant section of the northsouth part runs through Pałuki (Wągrowiec-Tarnowo Pałuckie-Lekno-Żnin-Wenecja-BiskupinGąsawa) (Figure 1).

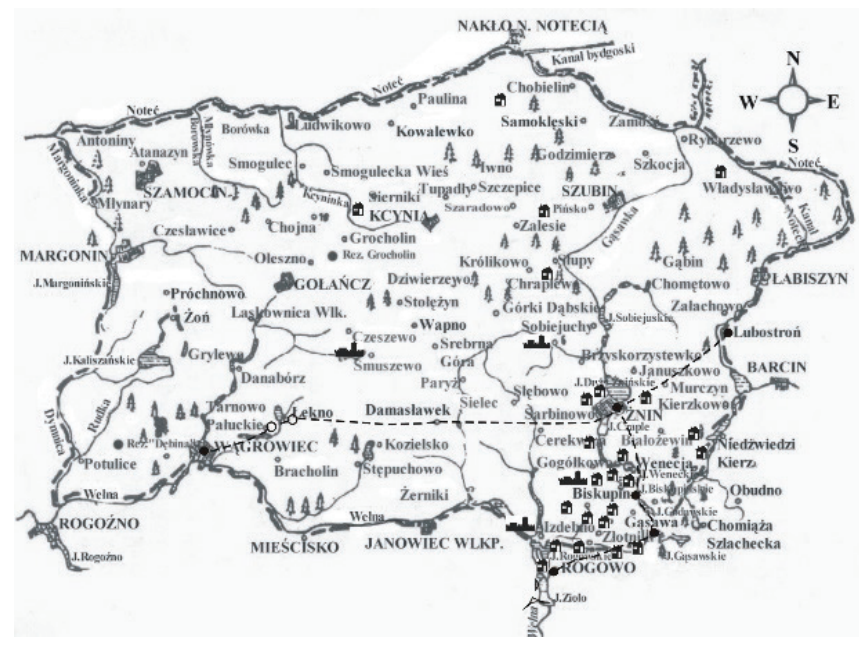

Hagritourism farms.

- - the course of the Piastowski Trail.

O locations waiting for being entered into the Piastowski Trail.

2,500 year ago old excavations and castle.

Figure 1. Location of agritourist farms in Pałuki (with the most important objects and tourist trails)

Source: own research on the basis of a map made available by the archive of the District Starosty in Żnin (http://znin.pl/pl/ contents/166).

\section{Results and Discussion}

The survey has proved that the agritourist facilities in Pałuki are very poorly developed and concentrated mainly in the south-east part of the region, that is, where the cultural resources, and natural conditions (that is, resources which can be used for recreation-forests, lakes), are the most abundant. The center of the region with few forests has no agritourist facilities at all. In the area of Łabiszyn-Szubin-Kcynia-Chodzież only a few agritourist farms were reported, although the region has both forest complexes and historical sites (Figure 1). Having been asked why so few people 
are involved in agritourism in the region the respondents indicated reluctance of farmers to undertake new challenges (46.1\%), existence of new, competitive accommodation facilities (87.5\%), lack of appropriate financial means to launch a small business (75\%) and fear of contact with tourists on an everyday basis (33.3\%). Agritourism, according to the respondents, is a serious challenge that requires initiative, creativity and willingness to introduce changes (79.1\%). Although all agritourist farm owners agree that Pałuki is an attractive region for tourists they do not take advantage of its cultural potential to make their offers more interesting. Analyzing the cultural heritage of Pałuki the respondents were of the opinion that, due to its location in the direct vicinity of numerous tourist attractions, Żnin should become its capital (81.8\%). Taking up common initiatives and strengthening mutual bonds, though very important elements of cooperation, were overlooked by the respondents. If agritourist farms cooperate with each other, this is only by sporadic exchange of guests (12.5\%). When it came to exchange of experience and tourist products, no cooperation was declared, though it could provide the farmers with mutual economic benefits. Some providers of agritourist services $(16.6 \%)$, though reported having made attempts to collaborate with others, stated that their initiatives usually did not work. This was caused by farmers' failing to keep the agreements. It turned out that the respondents did not belong to any organization supporting development of tourism or agritourism in the region.

The surveyed farm owners said that in spite of rich traditions of the region-a tourist is not very interested in them (62.5\%). According to them, visitors come to Pałuki to spend there a short time (2-5 days) and this is rather due to the natural advantage of the region not the cultural heritage. Such opinions were primarily connected with the profile of the farmers' own businesses. The hypothesis formulated at the beginning of the survey has not proved to be true as it turned out that despite declared affinity to the place of living, only $37.5 \%$ of agritourist farm owners found the local folklore to be attractive for tourists of Pałuki, whereas only one of them bases the business only on this aspect (Pałuki historical objects). According to Rogulska (2015, 22-23) the concept of 'folk culture' can be interpreted in many different ways, it is one of the developmental stages related to a given rural area and its community. Although the respondents do not promote folklore, they are able to indicate the most attractive elements of the Pałuki region. The most frequently indicated events and objects (95.8\%) were ethnographic museums (75\%), as well as traditional costumes $(25 \%)$, architectural objects $(83.3 \%)$ and the regional cuisine $(50 \%)$. They are also familiar with other objects and places connected with the culture of Pałuki, and they recommend to visit Biskupin and Żnin.

Apart from the above-mentioned locations, the respondents recommended to visit towns situated outside Pałuki, such as: Gniezno, Toruń, Lednicę, Inowrocław and Kruszwica. Despite having knowledge of tourist attractive sites in the Pałuki region (additionally, 79.1\% of farmers indicated such places as: Słupy, Wągrowiec, Grocholin and Lekno) they were not specific as to what is worth sightseeing there. Farmers did not take much trouble to highlight or promote these places in their tourist offers. Some of them did not even try to hide their lack of interest in providing their guests with attractions based on the cultural resources of the region. They were of the view that it is not payable (33.3\%). Only one farm owner offers his guests a tour around the region, with him being 
a guide, as he had completed a course for guides and knows places which, apart from Biskupin, Żnin and Wenecja, are worth visiting.

Rogulska emphasizes (2015, p. 61) the fact that currently the folk culture is not very trendy. It is surprising that agritourist farm owners take so little interest in this sphere of life. They are unwilling to enrich their offers with culture based aspects of the region, focusing only on recreation activities connected with water (fishing, rowing, canoeing) or forest activities (mushroom picking, hiking, cycling) (75\%). Attractions of agritourist offers also include: golf courses (1), horse riding camps (5), green schools (7). Only three farmers have tried to build the image on the basis of cultural heritage of the village and agriculture. First of all, they prepare special regional meals for their guests and they invite them to spend traditional Easter and Christmas holidays on the farm. A unique element of their offer are educational lessons and workshops for children, teenagers and adults. However, the activities offered by Pałuki-regional products which originated from historical times, are hard to find on offers of the analyzed farms. None of the respondents was involved in old trades or preserved old traditions. They were not interested in organization of live historical spectacles, which might be caused by the fact that tourist facilities located near the Archeological Museum in Biskupin can accommodate as many as 350 guests. Its perfect localization, competitive prices and rich recreational offer (workshops, region related theme trips) can significantly impede further development of the agricultural product of Pałuki, and the motivation to take up new challenges in this field. The respondents were of the opinion that potential visitors (41.6\%), who come to the Pałuki region would rather schedule their stay themselves (especially sightseeing), and their farms are treated as a place to spend the night in (sometimes they use board). Therefore, a significant group of the respondents $(45.8 \%)$ are interested in providing their guests with accommodation only, and they do not take the trouble to enter the market by offering additional attractions. On the other hand, Brzezińska (2009, p. 168) notices that this is the tourist who verifies what is necessary and useful. They are often city dwellers who happen to seek their cultural roots, and come to the village with their own plans and images, often idealized and mythical. If they do not find what they look for in the Pałuki Region, their stay will be short and no profits will be generated from it. The respondents observed that financial means obtained from the services they provide have significantly decreased during the last 5 years (75\%), therefore, in order to maintain the profit at a satisfying level they organize occasional events not connected with tourism $(62.5 \%)$. In six cases, the costs involved in running an agritourist business were higher than the profits (Figure 2). The information provided by respondents (19 farm owners) allows to conclude that the share of individual income from agritourism was $30 \%$ on the average and, in comparison with the data from 2008, it had increased by $1.7 \%$ (Cichowska, 2008, p. 237). As many as $42.1 \%$ of respondents declared the income share at the level of $30-55 \%$, the largest one (60-80\%) being reported for $15.8 \%$ of farm owners. For $26.3 \%$ of farms the income from agritourism accounts for $5 \%$ of their overall income, and for the remaining group it is (15.8\%) from 10 to $25 \%$. Figure 2 shows that this is the agricultural activity that accounts for the most of the farmers" income. This was $55.2 \%$, for a farm of average size equal to 7.6 ha. The question concerning estimated averaged costs of the yearly income from agritourism was answered by $70.8 \%$ of the respondents (that is 3 of whom did 


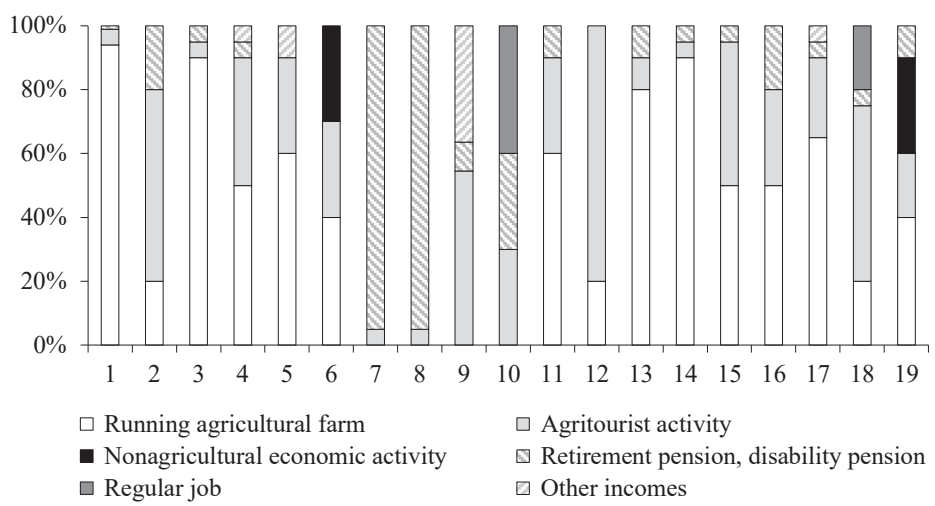

Figure 2. Estimated percentages of the shares of particular incomes (including agritourism) in overall incomes of the farms

Source: own study.

not provide information about the costs involved in running the farm, whereas 1 did not say what the yearly income was). It was found that for half of the respondents the average costs involved in providing agritourist services were lower than 5 thousand PLN and for $21.4 \%$ of farm owners they ranged from 6 to 10 thousand PLN (Figure 3). The highest costs were born by $14.3 \%$ of the respondents, that is, more than 30 thousand PLN, whereas the same percentage of the farmers declared having invested 20-30 thousand PLN. The analyzed costs were averaged to the level (calculated per 1 farm) of 10,721 PLN. The incomes were found to be higher and for the analyzed objects, were 13,411 PLN in 2016. For most of the farm owners the income was providing financial means in the amount of 5-10 thousand PLN (37.6\%) and below 5 thousand PLN (25\%).

An analysis of the income from agritourism allows to draw a conclusion that it provides most of the respondents (62.5\%) with fairly sufficient profits, even 35 or 39 thousand PLN (mainly farms with a long experience - 20 and 22years). The surveyed farm owners (91.6\%), stated that if the local authorities invested more funds into promotion of the cultural heritage of Pałuki, it would not only positively affect the development of cultural tourism in this area but also provide measurable financial profits both for the communes and for them (due to more visitors). Nevertheless, as Kosmaczewska and Górka (2009, p. 184) emphasize, unless agritourism is a large-scale enterprise (it is not in Pałuki), the profits it is likely to bring for agritourist farm owners and for the local communities are proportional to its size. Therefore, a promotion campaign should be undertaken to encourage farmers to get involved in agricultural services, and advertise the region whose history, geography and ethnography is undoubtedly very interesting and attractive. In the opinion of the respondents, the best way to promote the region is advertisement on TV (95.8\%), adverts in tourists' portals (62.5\%), in travel agencies (41.6\%), as well as at fairs and festivals (37.5\%). According to Piotrowski (2012, p. 18), is very important to provide information on the subject of the cultural 


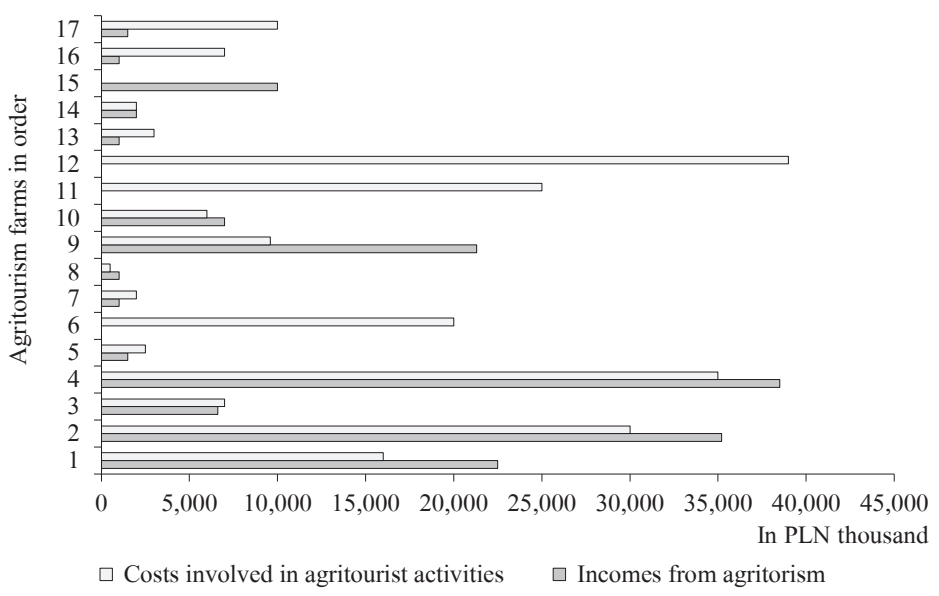

Figure 3. Estimated annual averaged costs and incomes from agritourist activity

Source: own study.

heritage especially that like all other people, its potential recipients, are bombarded with all kinds of information by all media so it can easily be overlooked by them. Pytel adds (2010, pp. 274-275), that only appropriate regional policy and reasonable spatial planning provides areas rich in objects of cultural value with the possibility of development. The respondents are of the view that not only the existing cultural advantages of the Pałuki region are the factors which determine the development of agritourist farms (and rural tourism in general), but also the tourist infrastructure and the level of technical infrastructure (transport connections, quality of roads). They identify the need to carry out a number of investments in order to improve the quality of both infrastructures $(83.3 \%)$. Baran and Szewc-Rogalska (pp. 509-510), observe a dependence of agricultural tourism on these factors and Zarębski (2015, p. 76) observes, on the basis of his research, that the spatial character of agricultural tourism and the individual character of the tourist products result in a small number of available accommodation facilities (for example Żnin district where between 2005-2017 the number of agritourist objects increased only by 6). Przezbórska-Skobiej (2016, p. 97) adds that although agritourism is considered to be an important indicator of the Polish farmers' entrepreneurship, given the share of agritourist farms in the total number of Polish farms $(0.58 \%$ of the total number of agricultural farms and $0.59 \%$ of the total number of individual farms), it can be said that it is of marginal character. The author of this study is of the opinion that this situation is also caused by the human factor. Rural population is often characterized by a passive attitude and lack of openness to introduce change. Creation of a well-considered, unique, and attractive agricultural products, based on the regional culture and tradition, could become the region specific offer, and like many other proposals discussed by Cichowska (2016, pp. 141-150), might be defined as 'Hits of Rural Tourism'. 


\section{Conclusions}

The carried out survey has proved that:

1. Development of agritourist farming does not depend on the cultural potential of the Pałuki region, though most farms are situated in the vicinity of the region major tourist attractions, concentrated in places such as: Biskupin, Żnin and Gąsawa. This attractive vicinity can have a negative influence on the local farmers' interest in getting involved into providing guests with recreation offers.

2. Proposals of spending leisure time in rural areas are not based on the cultural heritage of the region (according to the assumption accepted in the study), but rather on the natural attractiveness of the region. Most of agritourist offers include products based on the forest and water resources of the area.

3. Work on a farm (which, according to the survey results, is usually the major source of family maintenance) perhaps limits farmers' time to take up new investments and modify their offers. Therefore, the culinary factor can not only contribute to preservation of rural heritage but also to creation of special packets based on meal tasting and preparation and purchase of regional specialties. It would be a good idea to build a new culinary trail under the name 'Tastes of Pałuki'.

4. Culinary tourism can motivate not only farm owners but also the local community (boost development of agritourism). Culinary heritage of the Pałuki region can be used for educational, recreational and commercial purposes.

\section{References}

Baran, E., Szewc-Rogalska, A. (2011). Infrastruktura techniczna czynnikiem poprawy spójności społeczno-ekonomicznej obszarów problemowych Podkarpacia. Zeszyt nr 18 Uniwersytetu Rzeszowskiego. Nierówności społeczne a wzrost gospodarczy. Modernizacja dla spójności społeczno-ekonomicznej, 509-510.

Bednarski, L. (1998). Analiza finansowa. Warszawa: PWE.

Brzezińska, A.W. (2009). Specjaliści od kultury ludowej. Nauka, 3, 168.

Cichowska, J. (2016). Nowy produkt-nowa jakość, czyli jak zaistnieć na turystycznym rynku międzynarodowym. Ekologia i Technika, 3, 141-150.

Cichowska, J. (2008). Czynniki rozwoju agroturystyki na obszarach o niższych walorach przyrodniczych województwa kujawsko-pomorskiego. Doctoral dissertation. Toruń: Uniwersytet Mikołaja Kopernika w Toruniu.

Hełpa-Liszkowska, K. (2013). Dziedzictwo kulturowe jako czynnik rozwoju lokalnego. Studia Oeconomica Posnaniensia, $6(255), 8$.

Kosmaczewska, J., Górka, J. (2009). Ekonomiczne skutki rozwoju agroturystyki w opinii mieszkańców terenów wiejskich i lokalnych przedsiębiorców. Zeszyty Naukowe Uniwersytetu Szczecińskiego, 521. Ekonomiczne Problemy Turystyki, 11, 184.

Piotrowski, P. (2012). Promocja dziedzictwa kulturowego obszaru poprzez wydarzenie (na przykładzie IndustriadyŚwięta Szlaku Zabytków Techniki Województwa Śląskiego). Turystyka Kulturowa 10, 18.

Przezbórska-Skobiej, L. (2016). Agroturystyka jako forma przedsiębiorczości. In: A. Jęczmyk, J. Uglis, M. Maćkowiak (ed.), Turystyka Wiejska. Zagadnienia Ekonomiczne i Marketingowe, I. Poznań: Wydawnictwo Wieś Jutra Sp. z o.o.

Pytel, S. (2010). Rola turystyki kulturowej w rozwoju gmin województwa śląskiego. Krajobraz a Turystyka. Prace Komisji Krajobrazu Kulturowego, 14, 274-275. 
Rogulska, A. (2015). Czy komuś we współczesnej Polsce potrzebna jest kultura ludowa? In: A. Roguska, M. DanielakChomać (eds.), Uniwersalizm i tradycja w kulturze. Aktualności kultury ludowej. Część III (pp. 19-65). Siedlice: Pracownia Wydawnicza Wydziału Humanistycznego Uniwersytetu Przyrodniczo-Humanistycznego w Siedlicach.

Zarębski, P. (2015).Wybrane elementy turystyki kulturowej jako czynnik rozwoju bazy noclegowej na obszarach wiejskich w Polsce. Turystyka i Kultura, 1, 76. Retrieved from: http://turystykakulturowa.org/ojs/index.php/tk/article/ viewFile/527/508.

Ziernicka-Wojtaszek, A., Zawora, T. (2010). Dziedzictwo kulturowe obszarów wiejskich małopolski jako atrakcja agroturystyczna. Infrastruktura i Ekologia Terenów Wiejskich, 2, 120.

\section{DZIEDZICTWO KULTUROWE PAŁUK A ROZWÓJ AGROTURYSTYKI}

W REGIONIE

SŁOWA KLUCZOWE

STRESZCZENIE turystyka wiejska, agroturystyka, dziedzictwo kulturowe, Pałuki

Celem pracy było sprawdzenie czy wizerunek gospodarstw agroturystycznych współtworzony jest w oparciu o dziedzictwo kulturowe Pałuk. Badanie przeprowadzono drogą pogłębionego wywiadu telefonicznego przy użyciu anonimowego kwestionariusza. Odbyło się ono w 2017 roku w miesiącu maju i miało charakter wyczerpujący (wzięto pod uwagę wszystkie 24 zlokalizowane na Pałuckiej Ziemi pozarolnicze działalności). Zastosowana metoda pozwoliła na określenie czy w ocenie gospodarzy walory kulturowe analizowanego obszaru są atrakcyjne czy też nie. Ustalono również jak postrzegana jest przez gospodarzy promocja analizowanego regionu oraz czy dla pałuckich gmin turystyka kulturowa może przynieść wymierne korzyści ekonomiczne. 